\title{
UJI MEKANIK PLASTIK BIODEGRADABLE DARI PATI SAGU DAN GRAFTING POLY(NIPAM)-KITOSAN DENGAN PENAMBAHAN MINYAK KAYU MANIS (Cinnamomum burmannii) SEBAGAI ANTIOKSIDAN
}

\author{
Mechanical Test of Biodegradable Plastic Made from Sago Starch and \\ Grafting Poly(Nipam)-Chytosan with Additional Cinnamon Oil \\ (Cinnamomum burmannii) As Antioxidant
}

\author{
Isna Safitri, Medyan Riza, dan Syaubari \\ Jurusan Magister Teknik Kimia Universitas Syiah Kuala, \\ Jln. Tgk. Syech Abdulrauf No.7 Darussalam Banda Aceh \\ *e-mail: Isna_safitri@yahoo.com
}

Diterima: 17 November 2016, revisi akhir: 13 Desember 2016 dan disetujui untuk diterbitkan: 14 Desember 2016

\begin{abstract}
ABSTRAK
Plastik biodegradable adalah kemasan yang dapat diurai oleh mikroorganisme sehingga menjadi alternatif untuk menggantikan plastik kemasan konvensional yang menimbulkan permasalahan bagi lingkungan. Penelitian ini bertujuan untuk mengevaluasi pengaruh terhadap uji mekanisnya dan lain-lain yang terdiri atas tiga variabel dan masing-masing variabel terdiri dari tiga taraf kosentrasi. Variabel pertama adalah variasi penambahan grafting Poly(NIPAM)-kitosan yang terdiri dari kosentrasi 5\%, 7\% dan $9 \%$. Variabel kedua adalah variasi penambahan gliserol yang terdiri dari kosentrasi $15 \%, 30 \%$, $45 \%$ dan variabel ketiga adalah variasi penambahan minyak kayu manis yang terdiri dari kosentrasi $10 \%, 15 \%$ dan $20 \%$. Penelitian ini menghasilkan plastik berupa lembaran tipis, transparan, dan elastis serta memiliki warna bening sedikit kekuningan. Plastik yang dihasilkan memiliki nilai kuat tarik sebesar 1,34-2,57 MPa, elongasi 36,22- 66,30\%, dan penyerapan air 22,22\%-58,82\%. Hasil uji antioksidan dilakukan dengan membungkus apel dengan plastik biodegradable yang mengandung minyak kayu manis mampu menghambat pertumbuhan mikroorganisme, apel mengalami perubahan signifikan pada hari ke 8. Pada uji biodegrabilitas plastik ini terurai dalam tanah selama 56 hari.
\end{abstract}

Kata Kunci: Biodegradable, grafting, minyak kayu manis, pati sagu, plastik

\section{ABSTRACT}

Nonbiodegradable plastic is packaging that can be decomposed by microorganisms so that a viable alternative to replace conventional plastic packaging that cause problems for the environment. This study was aimed to evaluate the effect of the mechanical test and others consisting of three variables and each variable consists of three level of concentration. The first variable was additional grafting of Poly (Nipam) - chytosan consisting of 5\%, 7\% and $9 \%$. The second variable was additional glycerols which were $15 \%, 30 \%, 45 \%$. The third variable was concentrations of cinnamon oil which were $10 \%, 15 \%$ and $20 \%$. This research produced a thin sheet of plastic, transparant, and elastic and it had a slightly yellowish translucent color. The tensile strength value was about $1.34-2.57 \mathrm{MPa}, 36.22-66.30 \%$ of elongation value, and $22.22 \%-58.82 \%$ of water absorption. Antioxidant test was performed by wrapping an apple with biodegradable plastics containing cinnamon oil. It could inhibit the growth of microorganisms. The apples changed significantly on day 8. In biodegradability test, this plastic was decomposed after buried for 56 days in the soil.

Keywords: Biodegradable, grafting, cinnamon oil, sago starch, plastic 


\section{PENDAHULUAN}

Plastik banyak dimanfaatkan dalam berbagai keperluan manusia, mulai dari keperluan rumah tangga hingga keperluan industri. Pada umumnya, plastik digunakan sebagai kemasan. Hal ini disebabkan bentuknya yang elastis, berbobot ringan tetapi kuat, tidak mudah pecah, bersifat transparan, dan tahan air. Namun, pada kenyataannya plastik menimbulkan dampak negatif. Oleh karena itu perlu diciptakan plastik biodegradable. Salah satu bahan alam untuk pembuatan plastik biodegradable adalah kitosan. Kitosan merupakan modifikasi protein dari kitin yang ditemukan pada kulit udang, kepiting, lobster, dan serangga. Kitosan mempunyai sifat yang baik untuk dibentuk menjadi plastik dan mempunyai sifat anti mikrobakterial. (Sanjaya dan Puspita, 2011).

Selain itu N-Isopropilakrilamid (NIPAM) merupakan senyawa organik yang dapat disintesis menjadi polimer yang bersifat biodegradable. NIsopropilakrilamid (NIPAM) merupakan salah satu monomer akrilamid yang berwarna putih, tidak berbau, berbentuk kristal padat yang sangat mudah larut dalam air dan mudah bereaksi melalui reaksi amida atau ikatan rangkapnya. Senyawa ini dapat membentuk rantai polimer panjang yang disebut poly $(\mathrm{N}$ isopropilakrilamid) atau poly(NIPAM). Namun, poly(NIPAM) masih memiliki karakteristik yang kurang baik sehingga mulai banyak penelitian untuk memperbaikinya, salah satunya dengan melakukan cangkok (grafting) dengan monomer lainnya.

Plastik biodegradable juga dapat ditambahkan antioksidan berupa minyak kayu manis (Cinnamomum burmanii) salah satunya untuk menurunkan potensi oksidasi pada produk yang dibungkus. Minyak kayu manis memiliki kandungan sinamaldehida (51-76\%), eugenol, eugenol asetat, sinamil asetat, sinamil alkohol, metil eugenol, benzaldehida, benzil benzoat, linlool, monoterpana, hidrokarbon, kariofilena, safrol, dan lainnya (Zakaria et al., 2000).

Adapun tujuan dari penelitian ini yaitu untuk melihat pengaruhnya terhadap uji mekanik, daya serap air, dan uji biodegradable sebagai pengurainya serta menguji antioksidannya.

\section{METODOLOGI PENELITIAN}

Bahan yang diperlukan dalam penelitian ini adalah pati sagu, kitosan, gliserol, minyak kayu manis, asam asetat $2 \%$, etanol, monomer NIPAM, $\mathrm{NaOH}$, inisiator azobisisobutironiltril (AIBN), inisiator mercaptopropionic acid (MPA), aktivator N,N-dicyclohexyl carbomiide (DCC) dan aquades. Alat yang digunakan adalah beaker glass, erlenmeyer, gelas kimia, cetakan polietilen, batang pengaduk, pinset, timbangan analitik, hot plate, magnetic stirrer, aluminium foil, oven dan cawan petri.

Penelitian ini terdiri atas tiga variabel yang terdiri dari tiga taraf kosentrasi. Variabel utama adalah kosentrasi grafting poly(NIPAM)-kitosan (5\%, 7\%, dan $9 \%$ ), variabel kedua kosentrasi gliserol $(15 \%$, $30 \%, 45 \%$ ) dan variabel ketiga kosentrasi minyak kayu manis $(10 \%, 15 \%$, dan $20 \%)$.

\section{Pembuatan Plastik}

Pembuatan plastik biodegradable dari pati sagu dilakukan sebagai berikut: Pati sagu $5 \mathrm{gr}$ dilarutkan dengan $100 \mathrm{ml}$ aquadest dalam gelas kimia diaduk selama 25 menit. Setelah campuran tersebut homogen, larutan pati sagu dimasukkan ke dalam gelas kimia yang ditempatkan di atas hot plate. pemanasan dapat membantu meratakan distribusi panas. Pati dipanaskan hingga suhu $70^{\circ} \mathrm{C}$ selama 15-20 menit. Lalu ditambahkan plasticizer (gliserol), grafting poly(NIPAM)-kitosan dan minyak kayu manis ke dalam pati sagu. Pada saat penambahan gliserol, grafting poly(NIPAM)-kitosan, dan minyak kayu manis pati tersebut harus terus diaduk selama 15 menit untuk menghindari gumpalan dan mempercepat homogenisasi pencampuran antara pati sagu, grafting poly(NIPAM)-kitosan dan gliserol. Kemudian gelas kimia dipindahkan dari hot plate dan harus tetap diaduk sampai suhu normal sekitar $25-30^{\circ} \mathrm{C}$ selama 30 menit agar kekentalan tetap terjaga. Setelah larutan pati terbentuk pada suhu normal, dituangkan ke atas plat dengan ketebalan 
sekitar $1 \mathrm{~mm}$ yang telah diberikan lakban di pinggirannya. Lapisan tipis yang terbentuk di atas plat dimasukan ke dalam oven dengan suhu $40^{\circ} \mathrm{C}$ didiamkan selama 4 jam agar mengering. Lapisan tipis yang sudah mengering dilepaskan dari plat dengan cara membukanya dengan bantuan pisau silet yang tajam secara perlahan agar dapat lepas dari casting plat.

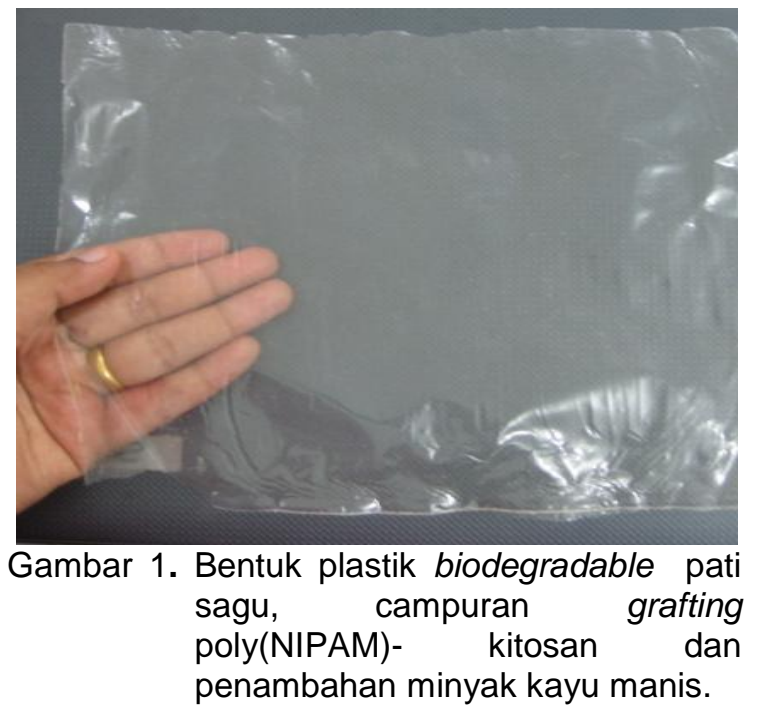

\section{Analisis}

Analisa dilakukan untuk mengetahui sifat mekanis dari plastik yang dihasilkan. Analisis meliputi kuat tarik, elongasi, daya serap air, uji antioksidan, dan uji biodegradabilitas.

\section{Hasil dan Pembahasan Kuat Tarik}

Kuat tarik merupakan gaya maksimum yang dapat ditahan oleh plastik hingga terputus. Pengujian ini bertujuan untuk mengetahui ketahanan suatu bahan terhadap pembebanan pada titik lentur dan juga untuk mengetahui keelastisan suatu bahan.

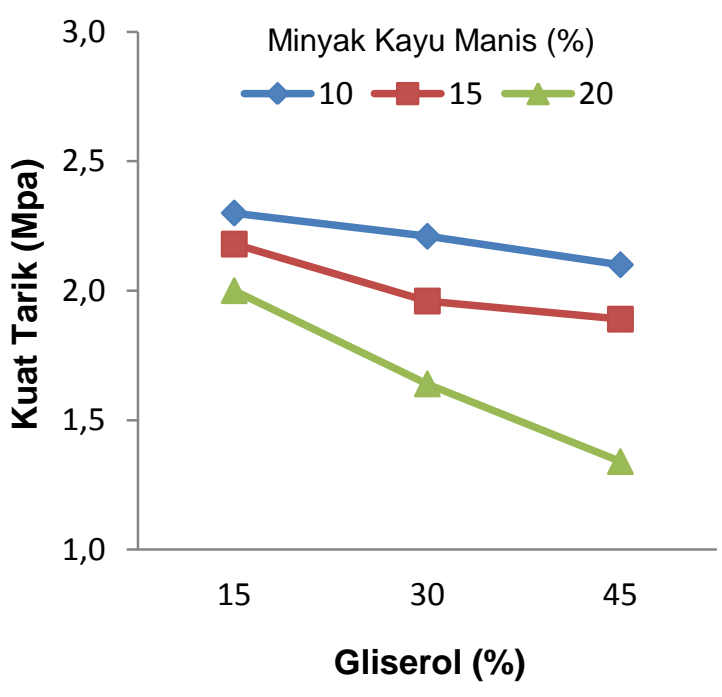

Gambar 2. Pengaruh konsentrasi grafting poly(NIPAM)-kitosan $5 \%$ dan berbagai kosentrasi gliserol serta minyak kayu manis terhadap kuat tarik plastik biodegradable.

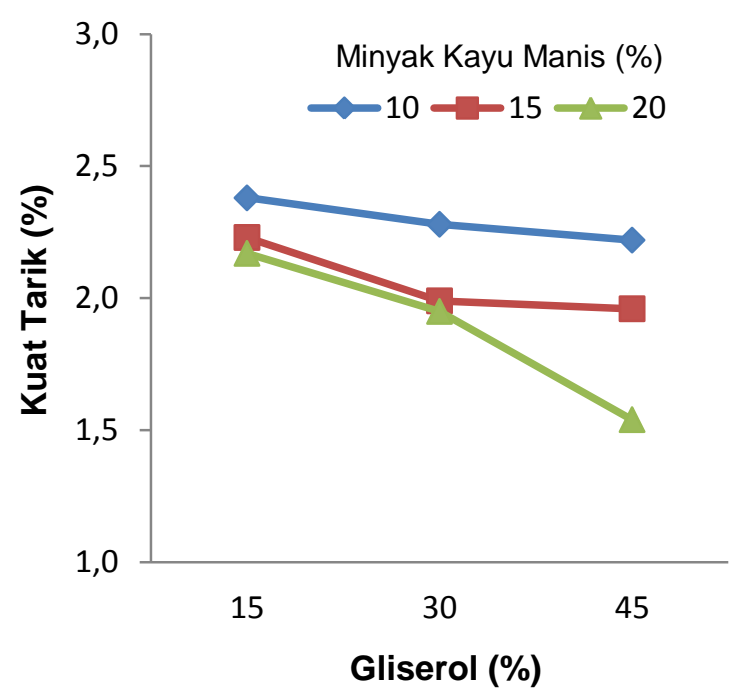

Gambar 3. Pengaruh konsentrasi grafting poly(NIPAM)-kitosan $7 \%$ dan berbagai kosentrasi gliserol serta minyak kayu manis terhadap kuat tarik plastik biodegradable. 


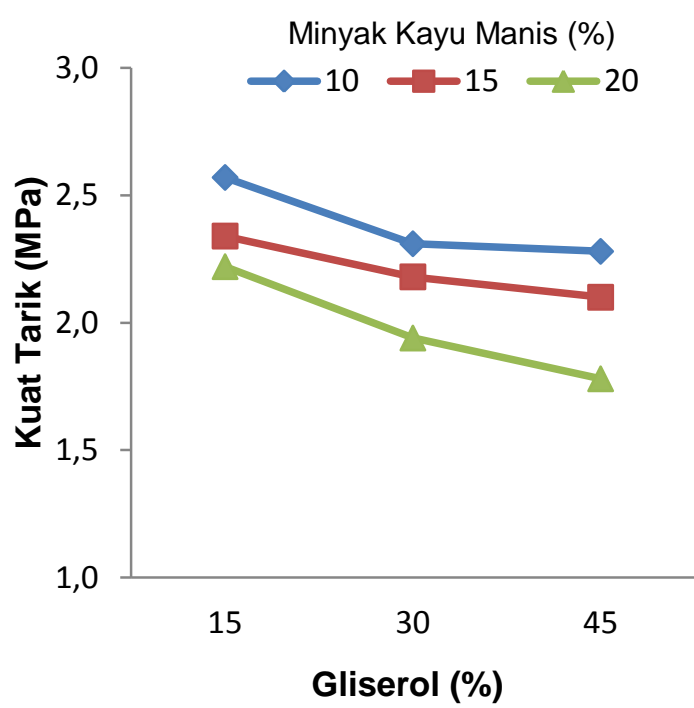

Gambar 4. Pengaruh konsentrasi grafting poly(NIPAM)-kitosan $9 \%$ dan berbagai kosentrasi gliserol serta minyak kayu manis terhadap kuat tarik plastik biodegradable.

Pada gambar 2,3 dan 4 dapat dilihat bahwa semakin tinggi konsentrasi grafting maka kuat tarik semakin meningkat. Hal ini disebabkan karena grafting merupakan gabungan kitosan dan poly(NIPAM) dimana kedua material tersebut merupakan polimer yang memiliki sifat penguat. Utari et al., (2008) menyebutkan jika plastik yang memiliki komponen kosentrasi kitosan dalam jumlah besar, maka nilai tensile strengthnya juga akan semakin besar. Hal ini dikarenakan semakin besar konsentrasi kitosan maka semakin banyak ikatan hidrogen yang terdapat dalam plastik sehingga ikatan kimianya akan semakin kuat dan sulit untuk diputus karena memerlukan energi yang besar untuk memutuskan ikatan tersebut. Akan tetapi nilai kuat tarik berbanding terbalik dengan adanya penambahan komposisi gliserol, dimana nilai kuat tarik akan semakin menurun seiring bertambahnya konsentrasi gliserol.

Oleh karena itu nilai kuat tarik tertinggi terdapat pada grafting $9 \%$, gliserol $15 \%$, dan minyak kayu manis $10 \%$ sebesar 2,57 $\mathrm{MPa}$ sedangkan nilai kuat tarik terendah diperoleh pada konsentrasi grafting $5 \%$, gliserol $45 \%$, dan minyak kayu manis $20 \%$ yaitu $1,34 \mathrm{MPa}$. Menurut Ojagh et al., (2010), penambahan minyak atsiri dapat menurunkan sifat mekanisnya sehingga menjadi lebih mudah patah. Hal ini disebabkan adanya fase minyak yang terdispersi dalam matriks film tersebut yang akan menyebabkan struktur filmnya mengalami proses diskontinuitas. Salah satunya nilai kuat tarik akan berkurang dengan adanya penambahan minyak kayu manis dibandingkan dengan kitosan murni tanpa penambahan minyak atsiri.

Seperti yang telah disebutkan oleh Utari, (2008) tentang penambahan gliserol, dari gambar 2, 3, dan 4 menunjukkan bahwa semakin tinggi gliserol maka nilai kuat tarik semakin menurun. Hal ini disebabkan karena bila gliserol tercampur dengan larutan polimer maka akan membentuk ikatan hidrogen antar molekul yang menyebabkan interaksi antar molekul polimer menjadi semakin berkurang sehingga mempermudah gerakan molekul polimer. Selain itu menurut Krochta et al., (1994) menyebutkan bahwa dengan meningkatnya plastisizer dapat menurunkan ikatan hidrogen dalam film. Oleh karena itu akan meningkatkan fleksibelitas yang menyebabkan film cenderung lentur sehingga dapat menurunkan nilai kuat tarik.

\section{Elongasi}

Elongasi adalah perpanjangan saat putus (elongation of break). Perpanjangan didefinisikan sebagai persentase perubahan panjang plastik pada saat ditarik sampai putus. Dari Gambar 5, 6 dan 7 dapat dilihat bahwa semakin besar komposisi gliserol maka persen elongasi juga semakin besar, yang berarti bahwa semakin banyak gliserol yang ditambahkan, maka sifat plastik akan semakin elastis. Plastisizer mampu mengurangi kerapuhan dan meningkatkan fleksibelitas plastik polimer dengan cara mengubah ikatan hidrogen antara molekul polimer yang berdekatan sehingga kekuatan tarik menarik inter molekul rantai polimer menjadi berkurang (Senny et al., 2012). Sedangkan persen elongasi berbanding terbalik terhadap konsentrasi grafting dan minyak kayu manis. Semakin besar konsentrasi kedua komponen tersebut, maka persen elongasi semakin 
menurun, Hal ini disebabkan oleh semakin menurunnya jarak ikatan intermolekulernya karena sama-sama mengandung gugus hidroksil.

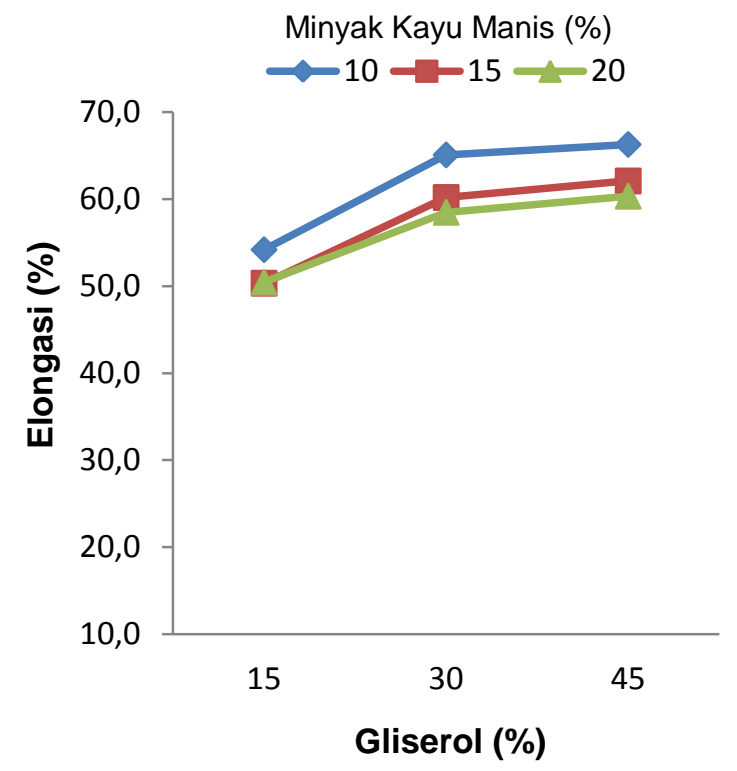

Gambar 5. Pengaruh konsentrasi grafting poly(NIPAM)-kitosan $5 \%$ dan berbagai kosentrasi gliserol serta minyak kayu manis terhadap elongasi plastik biodegradable.

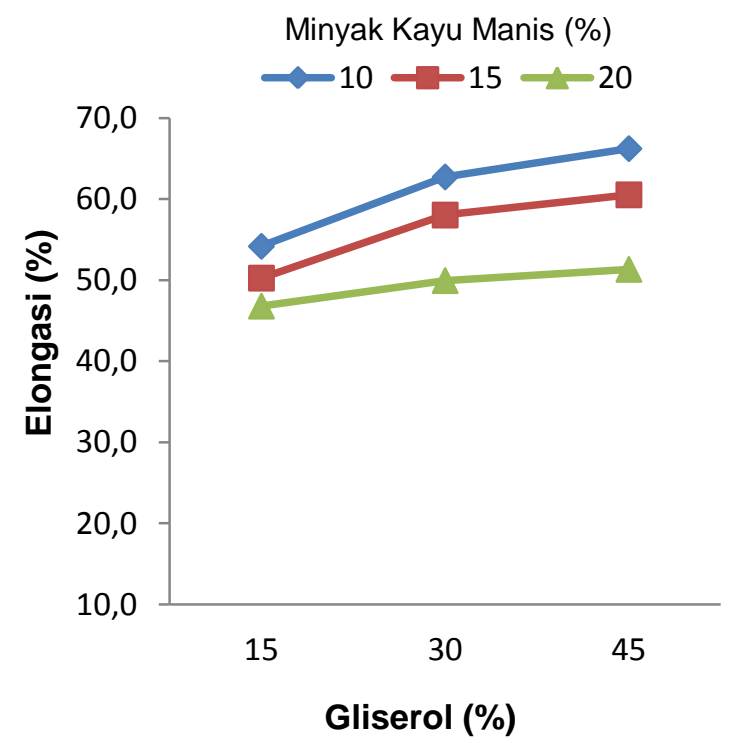

Gambar 6. Pengaruh konsentrasi grafting poly(NIPAM)-kitosan $7 \%$ dan berbagai kosentrasi gliserol serta minyak kayu manis terhadap elongasi plastik biodegradable.

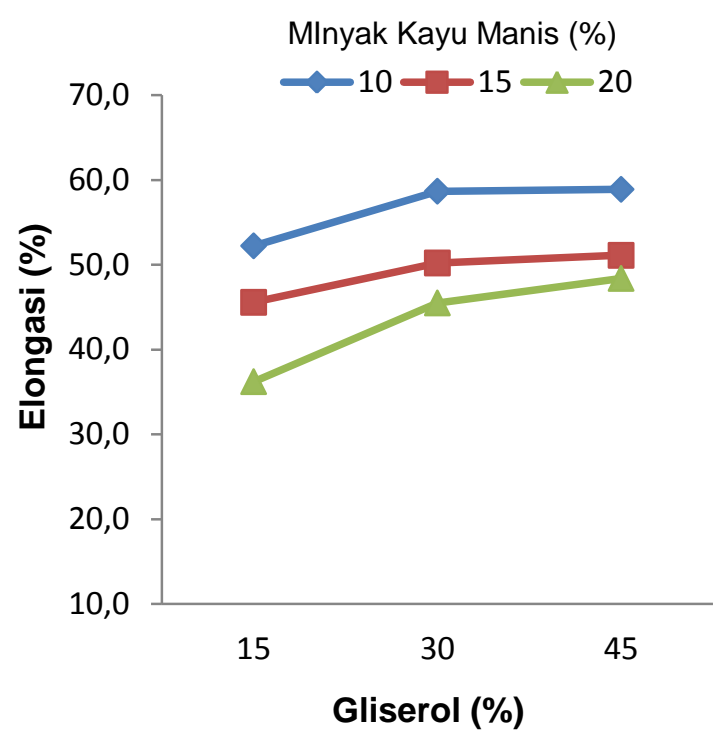

Gambar 7. Pengaruh konsentrasi grafting poly(NIPAM)-kitosan $9 \%$ dan berbagai kosentrasi gliserol serta minyak kayu manis terhadap elongasi plastik biodegradable.

Dari Gambar 5, 6, dan 7 dapat dilihat hasil elongasi terendah terdapat pada grafting $9 \%$, gliserol $15 \%$ dan minyak kayu manis 20\% didapatkan elongasi sebesar $66,30 \%$. Elongasi tertinggi pada sampel dengan kosentrasi grafting $5 \%$, gliserol $45 \%$, dan minyak kayu manis $10 \%$ dengan elongasi terbesar $36,22 \%$.

\section{Daya Serap Air}

Uji ini dilakukan untuk mengetahui terjadinya ikatan dalam polimer serta tingkatan atau keteraturan ikatan dalam polimer yang ditentukan melalui adanya penambahan berat polimer setelah mengalami penggembungan. Gambar 8, 9, dan 10 merupakan hasil uji daya serap air, dapat dilihat semakin tinggi penambahan grafting poly(NIPAM)-kitosan maka daya serap air semakin tinggi.

Pada konsentrasi grafting poly(NIPAM)-kitosan 9\%, gliserol 45\%, dan minyak kayu manis $10 \%$ nilai daya serap air mencapai $64,29 \%$ sedangkan daya serap air paling rendah berada pada konsentrasi grafting poly(NIPAM)-kitosan $5 \%$, gliserol $15 \%$, dan minyak kayu manis $45 \%$ yaitu $22,22 \%$. Sebagaimana yang di utarakan oleh Safwani (2014), bahwa 
tingginya daya serap air dengan semakin tinggi penambahan grafting poly(NIPAM)kitosan disebabkan karena banyak terdapat gugus hidrofil yang mampu mengikat air pada rantai polimer sehingga air akan terdifusi dalam polimer karena adanya gugus hidrofilik.

Setelah mencapai tahap kesetimbangan, air yang terserap akan terikat dengan gugus karboksilat membentuk ikatan hidrogen. Pada akhirnya air yang terserap akan tetap tertahan sehingga plastik akan mengembang. Begitu pula dengan penambahan gliserol, pada konsentrasi gliserol 45\% maka daya serap air semakin tinggi. Hal ini disebabkan karena gliserol termasuk zat yang mampu menyerap air dengan baik atau dikenal dengan sebutan higroskopis. Selain itu gliserol memiliki sifat hidrofilik sebagaimana yang dikatakan oleh Pramono et al., (2012) bahwa apabila suatu bahan memiliki gugus hidrofil maka bahan tersebut akan mudah berinteraksi dengan air.

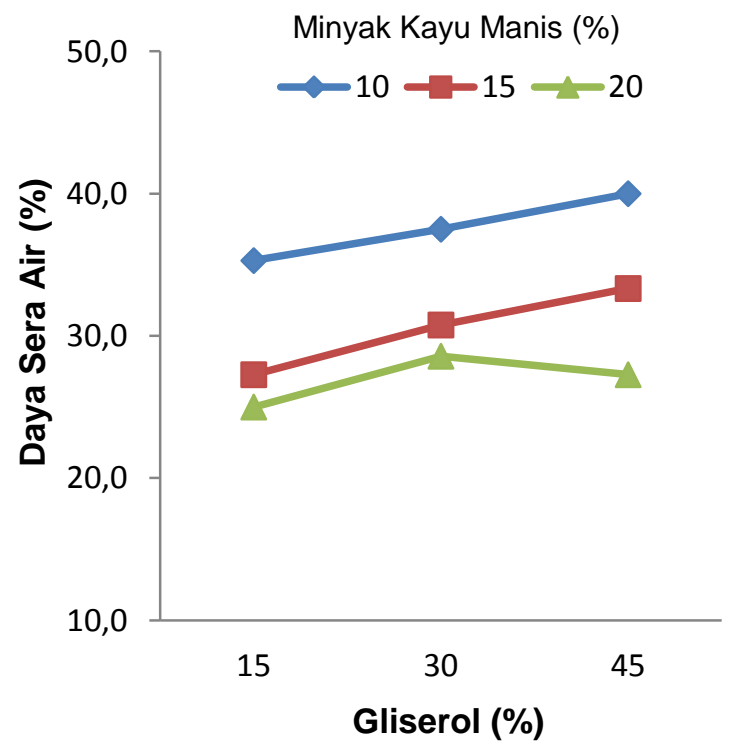

Gambar 8. Pengaruh konsentrasi grafting poly(NIPAM)-kitosan $5 \%$ dan berbagai kosentrasi gliserol serta minyak kayu manis terhadap daya serap air plastik biodegradable.

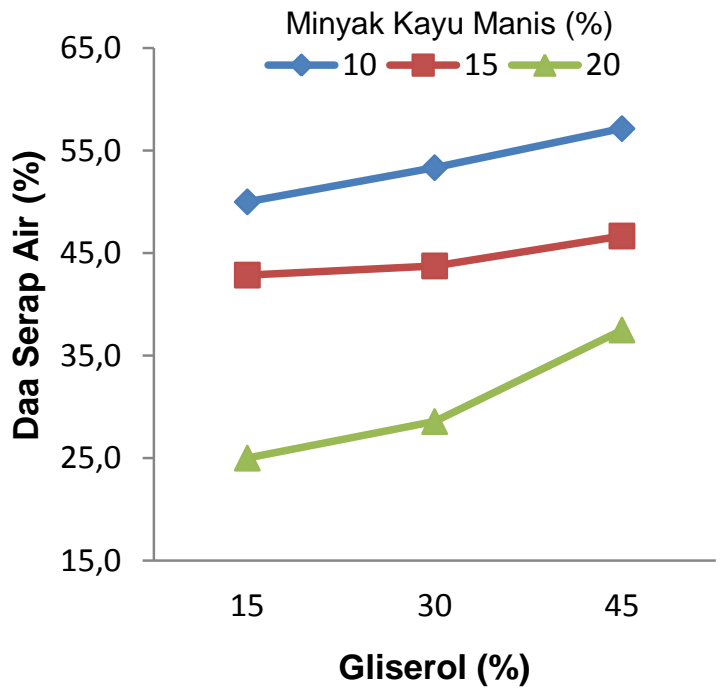

Gambar 9. Pengaruh konsentrasi grafting poly(NIPAM)-kitosan 7\% dan berbagai kosentrasi gliserol serta minyak kayu manis terhadap daya serap air plastik biodegradable.

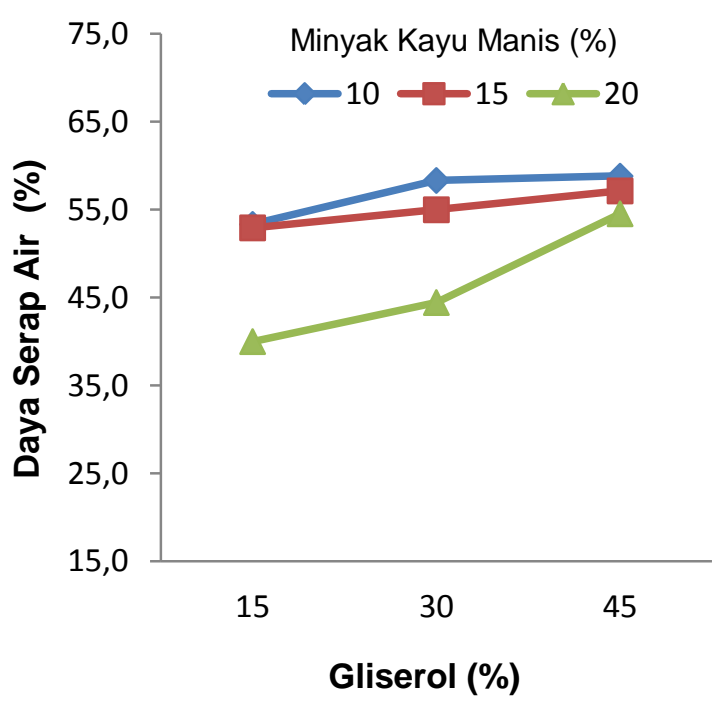

Gambar 10. Pengaruh konsentrasi grafting poly(NIPAM)-kitosan $9 \%$ dan berbagai kosentrasi gliserol serta minyak kayu manis terhadap daya serap air plastik biodegradable.

Irmayanti, (2015) juga menyebutkan penggunaan plastisizer yang semakin tinggi akan meningkatkan sifat adhesive antar molekul sehingga jumlah air yang 
terikat dengan senyawa polisakarida akan mengalami peningkatan yang menyebabkan kadar airnya semakin tinggi. Akan tetapi peningkatan daya serap air tidak terjadi pada penambahan minyak kayu manis karena minyak kayu manis merupakan bahan yang bersifat hidrofobik dan termasuk cairan nonpolar yang tidak dapat larut dalam larutan pati. Oleh karena itu, semakin tinggi konsentrasi minyak kayu manis maka persen daya serap air cenderung menurun. Dapat dilihat pada Gambar 8, 9, dan 10 daya serap air paling rendah terdapat pada konsentrasi minyak kayu manis $20 \%$.

\section{Uji Antioksidan}

Pada uji antioksidan dilakukan dengan cara membungkus sejenis buahbuahan yang bersifat mudah rusak atau perubahan secara mekanis. Apel merupakan salah satu buah yang cepat mengalami perubahan saat penyimpanan. Salah satunya adalah terjadinya reaksi browning atau pencoklatan. Gambar 11 merupakan pengujian antioksidan yang dilakukan dengan perbandingan pembungkusan apel dengan menggunakan plastik biodegradable pati sagu yang mengandung minyak kayu manis dan plastik biodegradable campuran pati dan gliserol serta apel tanpa dibungkus dengan plastik apapun (kondisi kontrol).

Pengamatan perubahan dilakukan setiap 2 hari sekali dalam jangka waktu sampai 8 hari. Hasil uji antioksidan menunjukkan pembungkusan dengan plastik biodegradable yang mengandung minyak kayu manis memiliki daya simpan relatif lama dibandingkan dengan apel tanpa pembungkusan dalam jangka waktu 2 hari sudah menunjukkan perubahan dari warna khas apel menjadi coklat. Apel dengan cepat terjadi pembusukan pada hari ke 8, warna apel menjadi hitam, mengeluarkan air dan bau tidak sedap yang disebabkan oleh adanya mikroorganisme pembusuk. Menurut Bachriansyah, 1997 pada makanan yang dikemas dalam plastik akan terjadi migrasi zat monomer dari bahan plastik ke dalam makanan, terutama jika kemasan tidak cocok dengan karakteristik makanan tersebut. Migrasi ini dipengaruhi oleh suhu makanan dan penyimpanan. Pembungkusan apel dengan plastik biodegradable tanpa minyak kayu manis apel menjadi layu dan menyusut. Hal ini diakibatkan penyerapan air dari plastik pembungkus tinggi.

Apel yang dibungkus dengan plastik biodegradable yang mengandung minyak kayu manis mengalami perubahan warna yang signifikan pada penyimpanan hari ke 8 akan tetapi tidak mengurangi aroma khas apel tersebut. Hal ini disebabkan karena pada plastik yang mengandung minyak kayu manis dan komponen kitosan memiliki bahan aditif yang dapat menghambat pertumbuhan mikroorganisme yang tidak diinginkan sehingga dapat memperpanjang penyimpanan suatu produk.

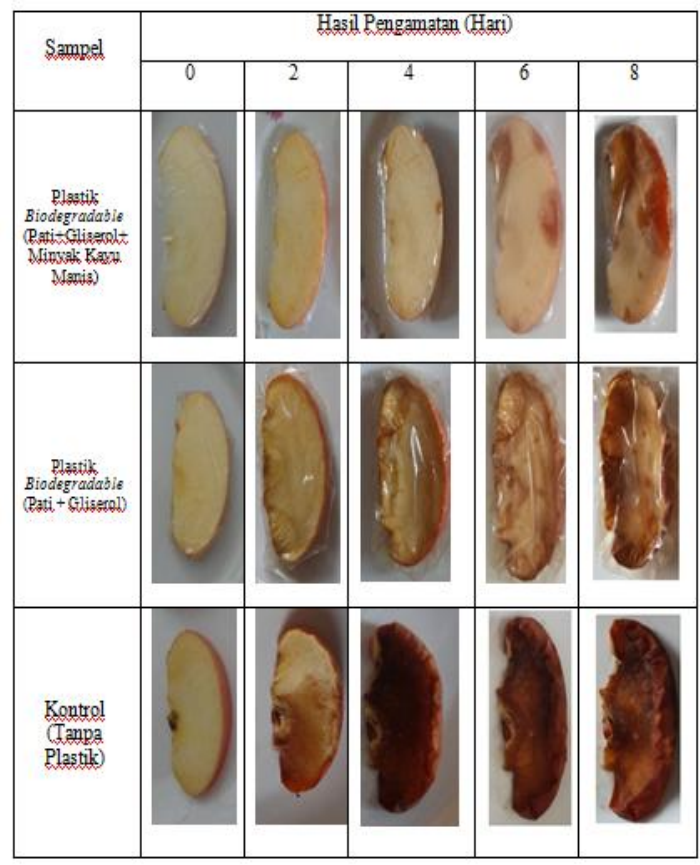

Gambar 11. Uji antioksidan pada irisan buah apel

Menurut Yuliarto dan Tri (2012) senyawa yang berperan sebagai antioksidan dalam mimyak kayu manis dalam jumlah yang besar yaitu sinnamaldehid sebesar $75,32 \%$ dan senyawa eugenol sebesar 8,53\%. Senyawa ini dapat mengurangi, mencegah atau memperlambat pertumbuhan mikroorganisme patogenik didalam pembungkusan makanan. Menurut Saleh et al., (2010) selain senyawa sinamaldehid dan eugenol, senyawa linalool juga bersifat 
antioksidan yang dapat memperbaiki sifat mekanis bahan makanan selama pembungkusan berlangsung. Menurut Gupta et al., (2008) minyak atsiri kayu manis sangat efektif dalam menghambat pertumbuhan beberapa bakteri antara lain $B$. cereus, $S$. aureus, E. coli, $P$. aeruginosa dan Klebsiella sp. Penghambatan bakteri dengan minyak atsiri kayu manis ini disebabkan oleh senyawa aktif seperti sinamaldehid dan asam sinnamat. Jadi selain antioksidan minyak atsiri kayu manis juga mempunyai efek antibakteri.

\section{Uji Biodegrabilitas}

Uji biodegrabilitas merupakan uji yang paling penting dalam menentukan waktu terurainya plastik dalam tanah. Plastik konvensional telah terbukti terurai dalam waktu sangat lama berkisar ratusan tahun, akan tetapi pada penelitian ini waktu degradasi paling lama yang dihasilkan adalah 56 hari dan paling cepat dalam waktu 14 hari. Proses degradasi yang terjadi adalah selulosa $\left(\mathrm{C}_{6} \mathrm{H}_{10} \mathrm{O}_{5}\right) \mathrm{n}$ yang merupakan komponen utama pada penelitian ini dipecah menjadi monomer glukosa dengan cara hidrolisis asam atau enzimatis.

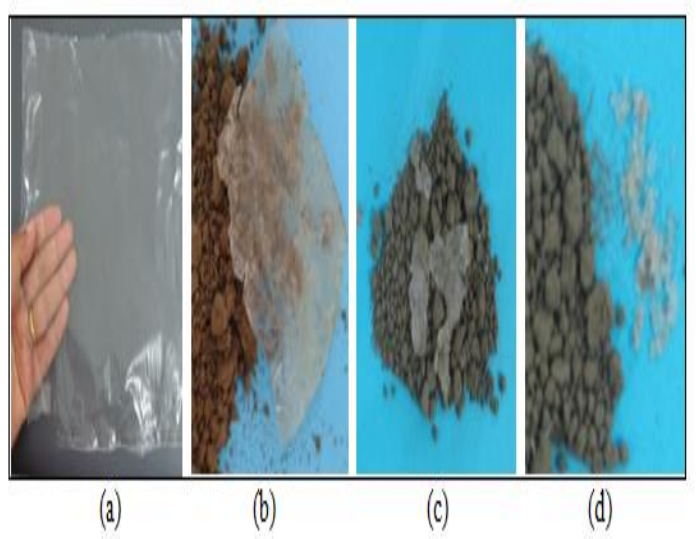

Gambar 12. Plastik biodegradable terurai di dalam tanah (a). 0 hari (b). 14 hari (c). 35 hari (d) 56 hari atau terurai sempurna.

Yang menentukan lama atau tidak plastik terurai adalah kandungan grafting dan minyak kayu manis. Semakin tinggi kosentrasi kedua komponen tersebut maka semakin lama waktu penguraiannya karena dua bahan tersebut mengandung sifat pengawet yang memperlambat aktifitas bakteri dalam tanah. Uji ini dilakukan dengan menimbun plastik ke dalam tanah dan diamati waktu perubahan atau penguraiannya setiap 7 hari sekali.

Gambar 12 merupakan salah satu sampel dari beberapa sampel lainnya yang paling lama terurai di dalam tanah yaitu dengan kosentrasi grafting 9\%, gliserol $15 \%$ dan minyak kayu manis $20 \%$. Dari Gambar dapat disimpulkan bahwa sampel mengalami kerusakan atau mulai terurai pada 14 hari dan pada hari ke 35 plastik mulai sobek dan patah terbagi menjadi beberapa bagian. Hal ini disebabkan karena adanya kehilangan massa dari plastik tersebut. Menurut Anita dan Harahap (2013) yang menyebabkan plastik menjadi demikian karena adanya kandungan gliserol dimana semakin tinggi gliserol maka semakin bersifat hidrofil karena gliserol dan pati memiliki gugus $\mathrm{OH}$ yang dapat menginisiasi reaksi hidrolisis, sehingga polimer tersebut menjadi potongan-potongan kecil.

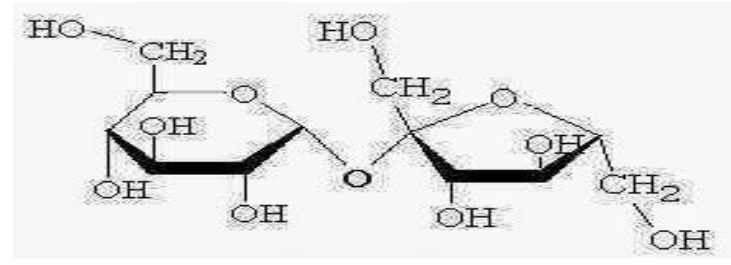

Gambar 13. Reaksi hidrolisis

Sedangkan pada hari ke 56 plastik terurai sempurna, plastik menjadi hancur dan berbentuk gumpalan serbuk sebagaimana asal bahan pembuatan plastik tersebut salah satu bahan utamanya yaitu pati sagu. Degradasi polimer dipengaruhi oleh komposisi, sifat polimer seperti berat molekul, suhu leleh, dan kristalinitas. Oleh karena itu semakin hidrofil maka polimer semakin cepat terdegradasi. Selain itu minyak kayu manis juga sangat berperan dalam proses degradasi ini karena dengan adanya minyak kayu manis dapat menghambat aktifitas bakteri. Akan tetapi plastik yang tidak mengandung unsur minyak kayu manis, dalam 14 hari sudah terurai sempurna. 


\section{KESIMPULAN}

Dari hasil penelitian dapat disimpulkan bahwa dengan penambahan grafting $9 \%$, gliserol $15 \%$, dan minyak kayu manis $10 \%$, uji mekanik kuat tarik plastik biodegradable terbaik sebesar 2,57 MPa. Sedangkan elongasi terbaik terdapat pada konsentrasi grafting $5 \%$, gliserol $45 \%$ dan minyak kayu manis $10 \%$ didapatkan elongasi sebesar 66,30\%. Hasil daya serap air paling baik berada pada konsentrasi grafting poly(NIPAM)-kitosan $5 \%$, gliserol $15 \%$ dan minyak kayu manis $45 \%$ yaitu $22,22 \%$. Penambahan minyak kayu manis pada plastik biodegradable mampu menghambat pertumbuhan mikroorganisme sehingga mampu menjaga masa simpan produk dan juga memperpanjang waktu penguraian plastik. Akan tetapi penambahan minyak kayu manis di atas $10 \%$ cenderung menurunkan sifat mekanis plastik.

\section{DAFTAR PUSTAKA}

Anita, Z. dan Harahap, H. 2013. Pengaruh waktu simpan film plastik biodegradasi dari pati kulit singkong terhadap sifat mekaniknya. Jurnal Teknik Kimia. 2 (2). Diakses pada 2 Oktober 2014.

Bachriansyah, S. 1997. Identifikasi plastik. Prosiding seminar teknologi pengemasan industri makanan dan minuman. Depertemen Perindustrian dan Perdagangan Bogor.

Gupta, C., Amar, P., Garg, R. C., Uniyal and Archana, K. 2008. Antimicrobial activity of some herbal oils againts common food-borne pathogens. African Journal of Microbiology Research Vol. 2: 258-261.

Irmayanti. 2015. Pembuatan plastik biodegradable dari pati bonggol pisang kepok dengan penambahan CMC (Carboxy methyl cellulose) dan minyak sereh sebagai antimikroba dan antioksidan. Rona Lingkungan Hidup (Journal Of Environment), BAPEDAL. Banda Aceh.
Krochta, J. M., Baldwin, E. A., dan Cariedo M.O.N. 1994. Edible coatings and films to improve food quality. Technomic Publishing, Co., Lancaster.

Ojagh, S. M., Rezaei, M., Razavi, S. H., \& Hosseini, S. M. H. 2010. Development and evaluation of a novel biodegradable film made from chitosan and cinnamon essential oil with low affinity toward water. Food Chemistry, 122, 161 and 166.

Pramono, E., Pandu, S. A. P., Candra, P., Jati, W. 2012. Pembuatan dan karakterisasi kitosan vanilin sebagai membran polimere elektrolit. Jurnal Penelitian Kimia. Vol 8 : 70-78.

Safwani, S. 2014. Sintesis plastik biodegradable dari tapioka dengan variasi perlakuan $\mathrm{N}$-Isopropilakrilamid (NIPAm) dan kitosan menggunakan gliserol sebagai plasticizer. Rona Lingkungan Hidup (Journal Of Environment), BAPEDAL. Banda Aceh.

Saleh, M, A., Clark, S., Woodard, B., and Sobogun, S. A. D. 2010. Antioxidant and free radical scavenging activities of essential oils. Ethnicity \& Disease, Vol. 20.

Sanjaya, I. G dan Puspita, T. 2011. Pengaruh penambahan kitosan dan plasticizer gliserol pada karakteristik plastik biodegradable dari pati limbah kulit singkong. Jurnal Jurusan Teknik Kimia, ITS. Surabaya.

Senny, W., Dewi, K., Yuni, T. N. 2012. Pengaruh penambahan sorbitol dan kalium karbonat terhadap karakteristik dan sifat biodegradasi film dari pati kulit pisang. Jurnal Program Studi Kimia, Fakultas Sains dan Teknik. Purwokerto.

Utari, H. 2008. Studi Pembuatan dan karakteristik sifat mekanik dan hidrofobisitas bioplastik dari pati sorgum. Jurnal Rekayasa Kimia dan Lingkungan. Vol.7. No. 4: 190-195. 
Yuliarto dan Tri, F. 2012. Pengaruh ukuran bahan dan metode destilasi (Destilasi air dan destilasi uap-air) terhadap kualitas minyak atsiri kayu manis (Cinnamomum burmannii). Universitas Negeri Sebelas Maret. Surakarta.
Zakaria, F. R., Susanto, H dan Hartoyo, A. 2000. Pengaruh konsumsi jahe (Zingiber officinale roscoe) terhadap kadar malonaldehida dan vitamin $\mathrm{E}$ plasma. Prosiding Teknologi dan Industri Pangan, XI (1), IPB, Bogor. 